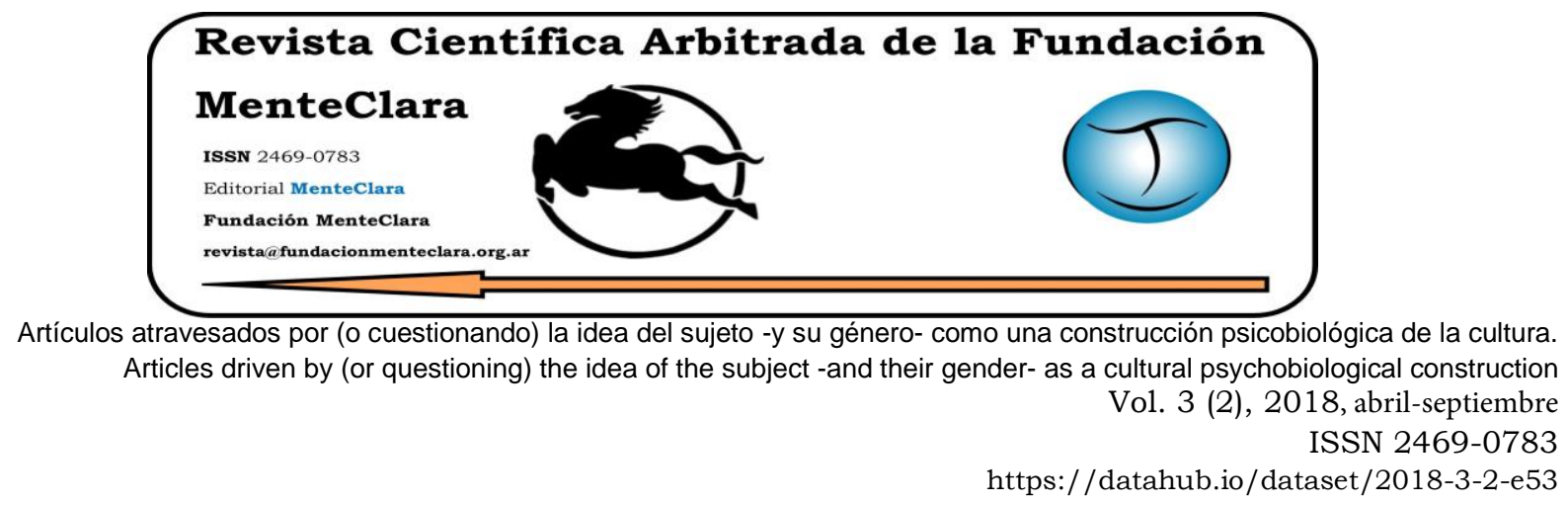

\title{
DESIRE AS THE EXPERIENCE OF SELF ARISING AWARENESS: A PHENOMENOLOGY
}

\author{
EL DESEO COMO LA EXPERIENCIA DE LA CONSCIENCIA AUTORREFERENTE: \\ UNA FENOMENOLOGÍA
}

Rudolph Bauer rbauer@rsbauer.net

Center for Consciousness Studies and Washington Center for Phenomenological and Existential Psychotherapy Studies. United States of America

Cómo citar este artículo / Citation: Bauer R. (2018). "Desire as the Experience of Self Arising Awareness: A Phenomenology". Revista Cientifica Arbitrada de la Fundación MenteClara, 3(2) abril-septiembre 2018, 133-144.

DOI: https://doi.org/10.32351/rca.v3.2.53

Copyright: (c) 2018 RCAFMC. Este artículo de acceso abierto es distribuido bajo los términos de la licencia Creative Commons Attribution-Non Commercial (by-cn) Spain 3.0. Recibido: 21/08/2018. Aceptado: 05/09/2018 Publicación online: $19 / 10 / 2018$

Conflicto de intereses: Ninguno que declarar.

\begin{abstract}
Desire is the Experience of Self Manifestation of the Field of Awareness. Desire arises out of Being's fullness and Being's unfolding creative momentum. Primordial desire is the felt sense of the self-manifestation of the essence of timeless awareness manifesting in time and in space. Desire is the dynamic heart of vital existingness. Vital-ness is the energetic aspect of Being. Dissociative Detachment from Desire is a Negation of Our Non Duality with Being.
\end{abstract}

\section{Resumen}

El deseo es la experiencia de la automanifestación del campo de la conciencia. El deseo surge de la plenitud del ser y del impulso creativo del ser que se despliega. El deseo primordial es el sentido de la automanifestación de la esencia de la conciencia 
eterna que se manifiesta en el tiempo y en el espacio. El deseo es el corazón dinámico de la existencia vital. La vitalidad es el aspecto energético del ser. El desapego disociativo del deseo es una negación de nuestra no dualidad con el ser.

\section{Palabras Claves/ Keywords}

Desire; Vitality; Detachment; Dissociation; Schizoid Life; Deseo; vitalidad; desapego; disociación; vida esquizoide 


\section{Awareness and the Experience of Being as Desire}

Our lack of awareness of Being results in bewildering experience. The intrinsic inner radiance, the inner light of Being arises out of primordial luminous spaciousness, the unbound openness of unbound pure potentiality. When this primordial ground of Being is veiled and obscured by the lack of experiential awareness, we can be locked into dualistic experiences, and consequently the non- dual nature of the field of Being is experientially foreclosed. The sense of indivisibility of all phenomena and awareness is experientially foreclosed. The capacity to see into, feel into and see through the lucidity of phenomena as the very field of Being becomes foreclosed and densified. We then live contained in mind alone. There is no experience of the field of Being. Without the field of Being we easily become things and objects both to our self and to others.

A defining characteristic of the mind is knowing beings and things. The mind knows forms. The mind does not directly know Being. Mind does not know the innate intimate ground of beings and things. The mind only knows duality, the mind knows difference. The mind only knows form.

A defining characteristic of awareness is that awareness directly knows Being and awareness directly knows non- duality. Awareness is capable of directly knowing the ground of Being of beings and things. All beings and all things are manifesting from and within this ground of Being. The ground of Being is not a being, but Being manifesting infinite beings. The ground of Being manifests everything and anything as Being itself. Being manifests the Being-ness of beings.

\section{Union of Mind within Awareness}

The wonderful union of mind and awareness allows us to know the Being-ness of beings, and the Being of a being. The wonderful union of 
mind and awareness allows us to know Being in singularity, the singularity of a person and the singularity of eventfulness, and the singularity of the being of a person and of a thing. The wonderful union of mind and awareness allows us to experience simultaneously oneness and difference. The union of mind and awareness allows us to experience the Being of a being which is Being itself. The wonderful union of mind and awareness allows us to experience non-duality within duality, and within duality to experience non- duality. Most amazingly the union of our mind and our awareness allows us to hold and experience time and timeless awareness simultaneously.

This cosmological manifesting of beings has double connotation. There is the connotation of bringing forth beings into existing-ness and there is the connotation as to the showing and shining forth of this existing-ness. A being is both existing and appearing. Being appears and shines through beings as Being. The unbound unfolding of our experiential knowingness, is the unfolding of our direct perception of Being's abiding nature. Our direct perception opens for us the profound experience of Being's pristine luminous knowingness as radiance.

Our experience of Being becoming beings brings forth for us the liberating experience of the nature of luminous reality manifesting as everything and anything. Gnosis is the direct experience of phenomena. This gnosis perceives the pervasive and expansive primordial radiance of the field of Being having become everything and anything. This is the great completeness.

\section{Desire as the Experience of Self Manifestation of the Field}

Desire is our unfolding experience of the self-manifestation of the field of Being. Desire is our self-arising of experience of this manifesting of primordial ground of Being. Desire arises out of Being's fullness and 
Being's unfolding creative momentum. Desire self- arises out of surplus, out of fullness. This Being of desire is manifesting everything and anything and saturates everything and anything. This fullness of desire is the fullness of self- manifestation of primordial field of luminous awareness.

The desire of Self- manifestation is the opposite of lack and the opposite of deprivation. Desire is not a need or need for a specific object or event. Desire is not neediness. Desire is not as some would have you think a psychological graspingness of desperate deprivation. Primordial desire is the felt sense of the self- manifestation of the essence of timeless awareness manifesting in time and in space. Timeless awareness itself is beyond time. Desire is timeless awareness becoming time. Desire is the living movement of Being itself. Desire is the felt sense of the manifestation of Being itself becoming everything and anything.

\section{Vital-ness}

Desire is the dynamic heart of vital existing-ness. Vital-ness is the being-ness of Being itself. Vital-ness is the energetic aspect of being. Desire manifests the being-ness of beings. Desire saturates the beingness of beings. Desire is the self- manifestation of Being as beings, desire is Being itself becoming being-ness and beings.

Desire is the movement of ground of Being's manifestation. Desire is the ground of Being's unfolding as the world. Desire is Being manifesting the being-ness of all beings. As Jacque Lacan once said in Baltimore "Desire creates Baltimore." Dzogchen is the experience of the intertwining of movement and awareness. As Garbe Dorge the ancient Dzogchen master explains there is no difference in being in movement and being in the state of stillness. Desire is the movement of being. 
There is this unceasing movement of appearing and disappearing of beings. Beings appear as the manifestation of Being and disappear into the sea of Being. The base of awareness is Being itself. Being is unborn and undying and Being is neither coming nor going. And yet the base of Being is unceasingly becoming beings in their coming and going, and in their appearing and disappearing, and in their eventual reappearing and disappearing.

\section{Self Liberation}

To experience this base of luminous awareness, this base of luminous Being is self- liberation. To experience the self- manifestation of the base of Being is liberation. Experiencing the Presence of Being manifesting and the presence of being disappearing within the presence of Being itself is self- liberation. Presence manifesting presence reveals and unveils the view that all presence manifests the one presence.

The pervasive and expansiveness of Being unceasingly manifesting, and unceasingly disappearing into its own presence is amazing. Being disappearing into own self manifestation is self- liberation.

The subjectivity of a living human being is essentially desire and the manifestation of desire. The great compassion itself in its original movement is desire. Desire is simultaneously the desire of a person as a person, and desire is also primordial ground of Being in its selfmanifestation. Desire is the field of Being manifesting manifestation. Desire is a field phenomena. Desire is the ground of Being manifesting Being through beings. Every being is a being of desire, every being is the self- manifestation of desire.

Desire manifests Being through beings. All beings are manifesting Being-ness through the desire of Being itself. Being which is not a being is the source of the manifestation of desire within and through beings. 
All desire is the manifestation of Being within beings. Beings manifests Being through the desire of self- manifestation.

The un-manifested ground of timeless awareness becomes manifested as time. Timeless awareness manifests time as time. Timeless awareness and time are indivisible. You and I are in time and in timeless awareness at the same moment. To hold time and timelessness simultaneously is self-liberation.

All movement is primordial vortices manifesting in time and is selfmanifesting forming time. The experience of movement is the experience of the sublime vibrational manifestation of ground awareness becoming everything and anything. The capacity to experience and to perceive the manifesting-ness of phenomena is self-liberation. The capacity to openly experience the disappearance of the self-manifestation of phenomena is liberation.

\section{Being is The Field}

Being is a field. The Being field is not a thing. The Being field is the field of beings as Being. The field is both the field of beings and the field of Being. And so there is the experience of the field of beings as the field of Being. This is the experience of duality within non-duality. This is the experience of non-duality within duality. This experience is selfliberation.

Our Dissociative Detachment from Desire Is a Negation of Our Non duality within Being

Unhappily, many philosophical and religious traditions relentlessly focus on the dissociation of desire as method and detachment as source for self- liberation. Liberation through negation. Dissociation from desire is considered to be the virtue of virtues. Dissociation is considered as a kind of holiness. This relentless religious focus on the negation of desire 
easily leads a person into sense of disembodiment and depersonalization. Depersonalization is the sense of non self, non- embodied self. This dissociative detached experience then becomes the philosophical assertions of anatman, the assertion of non self. This anatman philosophical speculation implies that the essence of the human being is lack, abyss like lack.

\section{As if is As if}

These fantasy-full traditions further emphasize the understanding that all experience is illusionary and all appearance is delusion. Nothing is real. Reality is non- existence. And thus liberation through negation becomes a tradition of belief and of philosophical orientation and practice. Existence becomes As If. As if is real; As if is actuality; all experience is As if.

Human experience is considered to be fantasy- full. These assumptions further increase the sense of our dissociation from the manifestation of our experience of the appearance of the world as Being. These anti desire traditions invalidate our experience of actuality and the felt sense of self. This repetitious enhancement of dissociative detachment separates us from our innate and immediate experience of the manifestation of desire as the manifestation of Being experience. This alienation of desire results in our lost connection with the primordial self-manifestation of Being becoming beings. The natural path of duality within non duality becomes the path of negation. Not this, and not that, and neither this nor that.

This dissociative preoccupation of detachment cuts us off from the natural intimacy of the self- liberation of self- manifestation. This relentless dissociation cuts us off from the natural path of experiencing non- duality within duality and duality within non- duality. 
Self- liberation loses its decisive naturalness and immediacy within our experience. This dissociative preoccupation cuts us off from the path of natural self- liberation and life of natural self-liberation. This praxis of dissociation tears us out of our natural state of oneness within the selfmanifestation of Being. This tear brings forth the terror of annihilation and destroys the natural experience of deathless awareness. This dissociative and pervasive view cut us off from the natural liberation of appearing and disappearing of phenomena. This dissociative compulsive driven-ness cuts us off from the indivisibility of all phenomena and our awareness. The sense of oneness within difference is destroyed and deconstructed.

\section{The Dissociative View}

This dissociative view brings forth a disembodied sense of self and dismembered sense of self. The natural sense of embodied Self is the experience of the self- manifestation of Being as our own being. The dissociative altitude towards embodiment tears and ruptures the experience of the body being the medium of the field. This dissociative view interferes and ruptures the natural unfolding process of embodiment of light. Liberation is the experience of the embodiment of luminous awareness within ourselves and within others; within everything and everyone.

Rather than the life of desire unfolding as the fullness of Being, life becomes nihilistic. Desire is considered to be a nasty graspingness. And so a person remains in dissociative detachment over time and the sense of self dissolves as well as the sense of immediate actuality of the field of Being dissolves. The natural life of self-liberation is perverted by dissociative negation. The relentless sense of dissociation from oneness brings forth the agony of deprivation and the terror of annihilation. 


\section{Schizoid Life}

Psychoanalytic scholars such as Fairbain, Winnicott, and Harry Guntrip have explored this dissociative detachment and have describe this inner psychological position as the anti- libidinal ego and as the schizoid position. This is another way of speaking about the force of antilife and anti- self-presence. These anti- desire religious or spiritual traditions have a distorted admiration of non- attachment, detachment and distant solipsistic existing-ness. Existential non relatedness is considered virtuousness. There is a focused attempt to cancel external relational life and live in detached and in everlasting withdrawal into inner void. This schizoid state is functionally to keep oneself emotionally out of reach, and keep the experience of everyone at arm's length. Arm's length is another word for detachment.

In many lineages and traditions attachment is considered a distortion of human relatedness. Being attached is considered spiritual distortedness and weakness. Being attached to persons is considered the source of all suffering. This understanding reflects the path of a schizoid spirituality. Liberation through schizoid-ness.

\section{Conclusion}

This preoccupation of detachment/negation is a preoccupation of many monastic based religious traditions. The method of negation of affectivity and the negation of bonded-ness leads to the ongoing experience of dissociative depersonalization. This in turn, brings forth the sense of absence of self and corresponding absence of self- agency. By living within depersonalization and absence of cohesive sense of self, the sense of actuality and the actuality of appearance soon come to be felt to as illusionary and life is experienced as deluded-ness. This view of 
nothingness or emptiness is nihilistic. This is not the sunyata of pure potentiality. This is not the creativity of primordial light as no-thingness. This is not the creativity of desire that brings forth everything and anything. This is not the creativity of love and generosity.

This unhappy religious delusion of dissociative/ detachment fractures our intimate and innate connection with the natural manifestation of the indivisibleness of phenomena and awareness. This detachment fragments human bonding and bonded-ness. The bonding to loved ones, the bonding to place and the bonding to Being is ruptured. Human bonded-ness is criticized as attachment. The natural sense of oneness within difference and difference within oneness is destroyed by such fractured thinking and teaching.

These traditions of liberation through the negation of desire are destructive to the unfolding of natural mystic humanism of human beings. 


\section{References}

Khandro S. (2014) "Love and liberation". Translated by Sarah Jacob.Columbia University Press.

Merleau-Ponty M. (1981) "The Phenomenology" by Gary Brent Madison. The Ohio University Press Series in Continental Thought.

Merleau Ponty M. (2010) "Institution and Passivity". Translated by Claude Lefort. Northwestern University Press.

Rabjam L. (2001 "A Treasure Trove of Scriptural Transmission". Edited by Richard Barron, Padma Publishing. 